Richards, F. A. (1966). Amer. f. Cardiol., 18, 384. Richardson, D. W., Freund, J., Gear, A. S., Mauck, H. P., and Preston,

Rose, G. A., Holland, W. W., and Crowley, E. A. (1964). Lancet, 1, 296.

Shinebourne, E. (1968). Cardiovasc. Res. In press.

Shinebourne, E., Fleming, J., and Hamer, J. (1967). Lancet, 2, 1217.
Somani, P., and Lum, B. K. B. (1965). F. Pharmacol. exp. Ther., 147, 194.

Stephen, S. A. (1966). Amer. F. Cardiol., 18, 463 Teotino, U. M., Polo Friz, L., Steis, G., and Della Bella, D. (1963).

Ulrych, M., Frohlich, E. D., Dustan, H. P., and Page, I. H. (1968). lation, 37, 411.

Waal, H. J. (1966). Clin. Pharmacol. Ther., 7, 588.

\title{
Acetazolamide and Sodium Bicarbonate in Treatment of Salicylate Poisoning in Adults
}

\author{
A. G. MORGAN,* M.B., M.R.C.P. ; A. POLAK, $†$ M.D., M.R.C.P.
}

Brit. med. F., 1969, 1, 16-19

\begin{abstract}
Summary: Ten adults suffering from salicylate over$S$ dosage were treated successfully with a combination of sodium bicarbonate and acetazolamide to exploit the increase in salicylate clearance which is known to occur in very alkaline urine. The advantages of the method include the absence of important complications and the small volume of fluid required.
\end{abstract}

\section{Introduction}

More than 20 years ago the renal clearance of free salicylate was shown to increase approximately fivefold when the $p \mathrm{H}$ of the urine was raised from 7 to 8 (Smith et al., 1946). Alkaline diuresis has since become an established method of treating salicylate overdosage, but its exponents-for example, Dukes et al., 1963 ; Beveridge et al., 1964 ; Matthew and Lawson, 1967-have laid more emphasis on achieving a high urine flow than on a very high urine $p H$. If this emphasis were reversed some of the hazards of a very rapid throughput of fluid might be avoided.

MacPherson et al. (1955) suggested the use of a combination of acetazolamide (Diamox) and sodium bicarbonate to maintain a urine of nearly maximal alkalinity. Either substance alone will have this effect, but with acetazolamide it wears off as the plasma bicarbonate and $\mathrm{pH}$ fall (Counihan et al., 1954); with bicarbonate it is sustained, though at the expense of some elevation of plasma bicarbonate and $\mathrm{pH}$ (Pitts et al., 1949). The combination should produce a sustained effect with little change in blood $p H$. However, where there is an initial metabolic acidosis, which makes some elevation of plasma bicarbonate and $\mathrm{pH}$ desirable, the effect of acetazolamide in delaying this elevation is likely to be slight (Schwartz et al., 1959). Though treatment with acetazolamide and bicarbonate has had varying success in children (Schwartz et al., 1959 ; Feuerstein et al., 1960), we feel that the results in a small series of adult patients are sufficiently favourable and consistent to warrant this report.

\section{Material and Methods}

Studies were made of 10 patients admitted to the Royal Portsmouth Hospital with moderate or severe salicylate intoxication. Details of the cases are included in Table I. Cases A and $B$ are listed separately because of minor deviations from the treatment regimen (see Results). Treatment was begun if

\footnotetext{
* Research Assistant.

† Consultant Physician. Unit, St. Mary's General Hospital, Portsmouth.
}

the serum salicylate level was above $50 \mathrm{mg} . / 100 \mathrm{ml}$. or if obvious clinical signs of salicylate intoxication were present.

On admission one venous blood sample was taken for salicylate estimation, and a second sample one hour later provided that treatment had not been started. A small-volume gastric lavage was performed. The patient was then catheterized, and closed bladder drainage set up. An intravenous infusion was started and $250 \mathrm{mg}$. of acetazolamide given intravenously.

Intravenous Infusion.-In the first hour, 1 litre of $1.4 \%$ sodium bicarbonate. In the second hour, 1 litre of $1.4 \%$ sodium bicarbonate plus $20 \mathrm{mEq} \mathrm{KCl}$. Then if the patient is still clinically dehydrated, 1 litre of $0.9 \%$ sodium chloride plus $20 \mathrm{mEq} \mathrm{KCl}$ hourly until the patient is rehydrated. If the patient is not clinically dehydrated (or when dehydration has been corrected by $0.9 \%$ sodium chloride), 1 litre of $1.4 \%$ sodium bicarbonate plus $40 \mathrm{mEq} \mathrm{KCl}$ two-hourly for four hours.

If treatment is still required (serum salicylate $>40 \mathrm{mg}$./ $100 \mathrm{ml}$. ) a further $250 \mathrm{mg}$. of acetazolamide is given intravenously and the following solutions are infused in rotation every two hours: (1) 1 litre of $0.9 \%$ sodium chloride plus $40 \mathrm{mEq} / \mathrm{KCl}$, and (2) 1 litre of $1.4 \%$ sodium bicarbonate plus $40 \mathrm{mEq} \mathrm{KCl}$.

The infusion should be stopped and this method of treatment abandoned if a positive fluid balance of two litres develops after the correction of dehydration.

On admission one venous blood sample was taken for salicylate estimation, and a second sample one hour later provided that treatment had not been started. A small-volume gastric lavage was performed. The patient was then catheterized, and closed bladder drainage set up. An intravenous infusion was started and $250 \mathrm{mg}$. of acetazolamide given intravenously.

The following investigations were carried out.

Clinical.-Frequent physical examinations were made, particular attention being given to the state of hydration and to cardiovascular, respiratory, and neurological disturbances.

Blood Samples.-Venous samples were taken on admission and after each litre of intravenous fluid, and the following serum constituents were measured: creatinine, sodium, total $\mathrm{CO}_{2}$, chloride, potassium, calcium, magnesium, and salicylate. Capillary blood pH measurements (Docrat and Kenny, 1965) were made initially, after two hours, and at the end of treatment.

Urine Samples.-Urine collections were made serially, each ending when a litre of fluid had been given intravenouslythat is, after one to two hours. Urine $p \mathrm{H}$ and volume were measured and an aliquot was refrigerated for creatinine, sodium, chloride, potassium, and salicylate estimation. 
TABLE I.-Details of Cases Studied

\begin{tabular}{|c|c|c|c|c|c|c|c|c|c|c|c|c|c|c|c|c|}
\hline \multirow[b]{2}{*}{$\begin{array}{l}\text { Case } \\
\text { No. }\end{array}$} & \multirow[b]{2}{*}{ Sex } & \multirow[b]{2}{*}{ Age } & \multirow{2}{*}{$\begin{array}{c}\text { Approx. } \\
\text { Dose } \\
\text { of } \\
\text { Aspirin } \\
\text { taken } \\
\text { (g.) } \\
\end{array}$} & \multirow{2}{*}{$\begin{array}{c}\text { Approx. } \\
\text { Time } \\
\text { before } \\
\text { Assess- } \\
\text { ment } \\
\text { (Hours) }\end{array}$} & \multirow{2}{*}{$\begin{array}{l}\text { Pre- } \\
\text { treatment } \\
\text { Serum } \\
\text { Salicylate } \\
\text { Level (mg./ } \\
100 \text { ml.) } \\
\end{array}$} & \multirow[b]{2}{*}{$S_{0} \ddagger$} & \multicolumn{10}{|c|}{ Summary of Clinical State } \\
\hline & & & & & & & $\begin{array}{c}\text { Impair- } \\
\text { ment of } \\
\text { Con- } \\
\text { sciousness }\end{array}$ & Shocked & $\left|\begin{array}{c|}\text { Convul- } \\
\text { sion } \\
\text { Prior to } \\
\text { Treatment }\end{array}\right|$ & $\begin{array}{c}\text { Rest- } \\
\text { lessness }\end{array}$ & $\begin{array}{c}\text { Hyper- } \\
\text { ventilation }\end{array}$ & $\begin{array}{l}\text { Vomit- } \\
\text { ing }\end{array}$ & $\begin{array}{c}\text { Sweat- } \\
\text { ing }\end{array}$ & $\begin{array}{l}\text { Dehy- } \\
\text { dration }\end{array}$ & $\begin{array}{l}\text { Deaf- } \\
\text { ness }\end{array}$ & $\underset{\text { tus }}{\text { Tinni- }}$ \\
\hline $\begin{array}{r}1 \\
2 \\
* 3 \\
4 \\
5 \\
6 \\
7 \\
8\end{array}$ & $\begin{array}{c}\mathbf{F} \\
\mathbf{M} \\
\mathbf{F} \\
\mathbf{M} \\
\mathbf{M} \\
\mathbf{F} \\
\underset{M}{\mathbf{M}}\end{array}$ & $\begin{array}{l}19 \\
35 \\
28 \\
33 \\
23 \\
17 \\
39 \\
26\end{array}$ & $\begin{array}{l}33 \\
45 \\
- \\
26 \\
24 \\
33 \\
45\end{array}$ & $\begin{array}{r}8 \\
12 \\
12 \\
9 \\
12 \\
4 \\
6 \\
6\end{array}$ & \begin{tabular}{|l}
51 \\
54 \\
80 \\
52 \\
69 \\
51 \\
77 \\
60
\end{tabular} & $\begin{array}{r}60 \\
70 \\
105 \\
65 \\
91 \\
89 \\
89 \\
70\end{array}$ & $\begin{array}{l}- \\
\overline{+} \\
\pm \\
= \\
\pm \\
\pm\end{array}$ & $\begin{array}{l}\bar{z} \\
\bar{z} \\
\bar{z} \\
=\end{array}$ & $\begin{array}{l}- \\
\pm \\
\pm \\
= \\
\pm\end{array}$ & $\begin{array}{l}\overline{+} \\
\pm \\
\pm \\
\overline{-} \\
\overline{-}\end{array}$ & $\begin{array}{l}- \\
+ \\
+ \\
+ \\
+ \\
+ \\
+\end{array}$ & $\begin{array}{l}+ \\
+ \\
- \\
- \\
+ \\
-\end{array}$ & $\begin{array}{l}\overline{+} \\
+ \\
\pm \\
\overline{-} \\
\overline{+}\end{array}$ & $\begin{array}{l}- \\
+ \\
+ \\
+ \\
+ \\
- \\
-\end{array}$ & $\begin{array}{l}+ \\
+ \\
+ \\
+ \\
+ \\
+ \\
+\end{array}$ & $\begin{array}{l}+ \\
+ \\
+ \\
+ \\
+ \\
+\end{array}$ \\
\hline$\underset{B}{+A}$ & $\underset{\mathrm{F}}{\mathrm{M}}$ & $\begin{array}{l}41 \\
21\end{array}$ & $\begin{array}{l}45 \\
33\end{array}$ & $\begin{array}{l}7 \cdot 5 \\
5 \cdot 5\end{array}$ & $\begin{array}{l}81 \\
88\end{array}$ & $\begin{array}{r}94 \\
109\end{array}$ & \pm & \pm & \pm & $\bar{t}$ & + & $\overline{-}$ & + & \pm & $\overline{+}$ & $\bar{t}$ \\
\hline
\end{tabular}
have resulted if absorption had been immediate and complete (see text).

\section{Laboratory Methods}

Serum creatinine, sodium, total $\mathrm{CO}_{2}$, chloride, potassium, and urinary creatinine were estimated on a Technicon AutoAnalyzer. Urinary sodium, chloride, and potassium were measured in the early part of the study by an E.E.L. flame photometer, and later by a Unicam S.P.90 flame photometer, which was also used to measure calcium and magnesium. All pH measurements were made at $37^{\circ}$ C. on a Radiometer capillary $\mathrm{pH}$ meter No. 27 . Serum salicylate concentration was estimated by the method of Trinder (1954). Urinary salicylic acid concentration was measured by a modification of the method of Brodie et al. (1944).

\section{Derived Data}

Serum salicylate half-life was derived from semilogarithmic plotting of the serum salicylate level against time.

Salicylate and creatinine clearances were calculated by using the mean of the initial and final serum levels for each clearance period.

$S_{0}-S_{0}$, the serum salicylate level which would have resulted had absorption been immediate and complete was calculated by the method of Done (1960), who took an $S_{o}$ value above 100 as an indication of severe poisoning. His calculation assumed a half-life of 20 hours in the untreated patient.

Cumulative balances for water, sodium, chloride, and potassium were estimated by subtracting the urinary output from the amount infused. No vomiting occurred during treatment.

Mean urine $\mathrm{pH}$ was calculated by converting to hydrogen ion concentration, taking an arithmetic mean, and converting this value back to $p \mathrm{H}$.

\section{Results}

Clinical.-Complete recovery occurred in all the patients in this study. No cardiovascular or neurological complications were encountered during treatment. The patients in whom there was initial dehydration are indicated in Table I. It will be noted from Table III that these are the patients who were allowed to accumulate a positive fluid balance in excess of two litres.

Biochemical and Balance Data.-Biochemical and balance data are given in Table II, which contains data relating to the removal of salicylate, and Table III, which contains data relating to freedom from complications. Serum calcium and magnesium did not change significantly, and are therefore not included in Table III. Cases A and B are listed separately in the tables because their treatment included an extra litre of bicarbonate where the treatment regimen prescribed normal saline. Their maximum blood $\mathrm{pH}$ was recorded following this deviation from the regimen. These two cases are excluded from the calculation of group averages. The fall in serum salicylate during treatment is depicted in Fig. 1 and the relationship of salicylate and creatinine clearances is shown in Fig. 2.

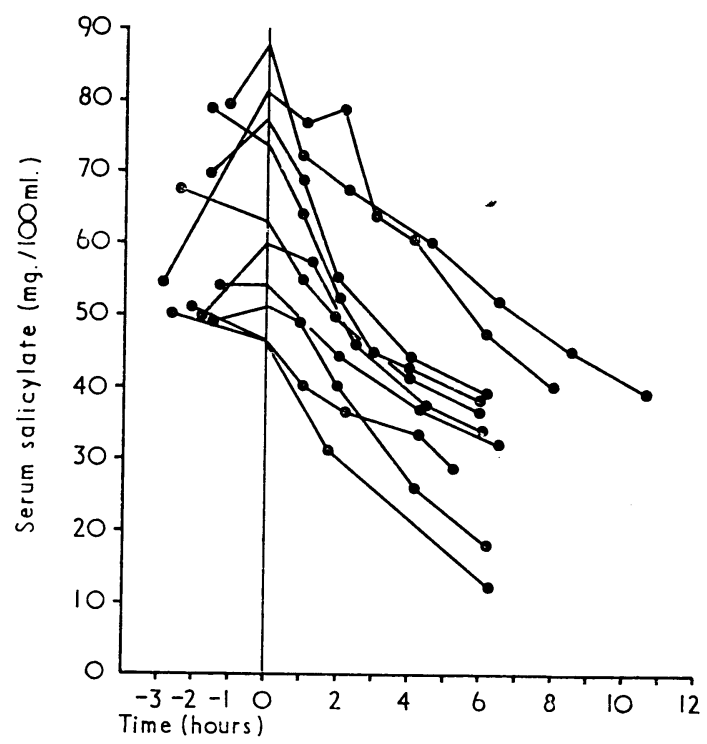

FIG. 1.-Serum salicylate levels in 10 patients prior to treatment, and the rate of fall during treatment.

TABLE II.-Data Relating to Salicylate Elimination

\begin{tabular}{|c|c|c|c|c|c|c|c|c|c|}
\hline $\begin{array}{l}\text { Case } \\
\text { No. }\end{array}$ & $\begin{array}{c}\text { Initial } \\
\text { Serum } \\
\text { Salieylate } \\
\text { (mg./100 ml.) }\end{array}$ & $\begin{array}{c}\text { Salicylate* } \\
\text { Half-life } \\
\text { (Hours) }\end{array}$ & $\begin{array}{l}\text { Average } \\
\text { Urine } \\
\text { Flow } \\
\text { (ml./min.) }\end{array}$ & $\begin{array}{c}\text { Mean* } \\
\text { Urine } p H\end{array}$ & $\begin{array}{c}\text { Maximum } \\
\text { Recorded } \\
\text { Urine } \\
p \mathrm{H}\end{array}$ & $\begin{array}{c}\text { Lowest } \\
\text { Recorded } \\
\text { Urine } \\
p \mathrm{H}\end{array}$ & $\begin{array}{c}\text { Pretreatment } \\
\text { Urine } \\
p \mathrm{H}\end{array}$ & $\begin{array}{c}\text { Length of } \\
\text { Diuretic } \\
\text { Treatment } \\
\text { (Hours) }\end{array}$ & $\begin{array}{l}\text { Urinary } \\
\text { Salicylic Acid } \\
\text { Recovered } \\
\text { (g.) }\end{array}$ \\
\hline $\begin{array}{l}1 \\
2 \\
3 \\
4 \\
5 \\
6 \\
7 \\
8\end{array}$ & $\begin{array}{l}51 \\
54 \\
80 \\
52 \\
69 \\
51 \\
77 \\
60\end{array}$ & $\begin{array}{l}3 \cdot 2 \\
8 \cdot 5 \\
5 \cdot 8 \\
7 \cdot 4 \\
7 \cdot 8 \\
4 \cdot 2 \\
6 \cdot 4 \\
7 \cdot 3\end{array}$ & $\begin{array}{l}7 \cdot 2 \\
2.8 \\
2.6 \\
4.0 \\
4.3 \\
7.0 \\
7.7 \\
5.0 \\
\end{array}$ & $\begin{array}{l}7.93 \\
7.95 \\
7.95 \\
7.95 \\
7.83 \\
7.85 \\
7.78 \\
7.85\end{array}$ & $\begin{array}{l}8.0 \\
8.0 \\
7.99 \\
8.0 \\
7.92 \\
7.95 \\
7.87 \\
7.92\end{array}$ & $\begin{array}{l}7.75 \\
7.87 \\
7.81 \\
7.75 \\
7.55 \\
7.78 \\
7.6 \\
7.64 \\
\end{array}$ & $\begin{array}{l}6.8 \\
7.05 \\
7 \cdot 3 \\
6.5 \\
6.35 \\
6.88 \\
6.85 \\
6.87\end{array}$ & $\begin{array}{l}6 \cdot 25 \\
6 \cdot 5 \\
7 \cdot 0 \\
5 \cdot 25 \\
6 \cdot 0 \\
6 \cdot 0 \\
6 \cdot 25 \\
6 \cdot 25\end{array}$ & $\begin{array}{l}4 \cdot 2 \\
4 \cdot 6 \\
4 \cdot 8 \\
2 \cdot 2 \\
3 \cdot 9 \\
6 \cdot 0 \\
7 \cdot 1 \\
6 \cdot 5\end{array}$ \\
\hline Av. & & $6 \cdot 3$ & $5 \cdot 2$ & $7 \cdot 88$ & 7.96 & $7 \cdot 72$ & 6.82 & $6 \cdot 2$ & \\
\hline $\begin{array}{l}\mathrm{A} \\
\mathrm{B}\end{array}$ & $\begin{array}{l}81 \\
88\end{array}$ & $\begin{array}{l}9 \cdot 8 \\
7 \cdot 0\end{array}$ & $\begin{array}{l}6 \cdot 3 \\
6 \cdot 7\end{array}$ & $\begin{array}{l}7 \cdot 65 \\
7 \cdot 85\end{array}$ & $\begin{array}{l}7.9 \\
7.98\end{array}$ & $\begin{array}{l}7 \cdot 34 \\
7 \cdot 55\end{array}$ & $\begin{array}{l}5.9 \\
6.55\end{array}$ & $\begin{array}{r}10 \cdot 5 \\
8 \cdot 0\end{array}$ & $\begin{array}{l}9 \cdot 8 \\
6 \cdot 6\end{array}$ \\
\hline
\end{tabular}


TABLE III.-Data Relating to Freedom from Complications

\begin{tabular}{|c|c|c|c|c|c|c|c|c|c|}
\hline $\begin{array}{l}\text { Case } \\
\text { No. }\end{array}$ & $\begin{array}{c}\text { Length of } \\
\text { Diuretic } \\
\text { Treatment } \\
\text { (Hours) }\end{array}$ & $\begin{array}{c}\text { I.V. } \\
\text { (Litres) }\end{array}$ & $\begin{array}{c}\text { Maximum } \\
\text { Positive } \\
\text { Fluid Balance } \\
\text { (Litres) }\end{array}$ & $\begin{array}{c}\text { Maximum } \\
\text { Cumulative } \\
\text { Sodium Balance } \\
(\mathrm{mEq})\end{array}$ & $\begin{array}{c}\text { Minimum } \\
\text { Cumulative } \\
\text { Potassium } \\
\text { Balance (mEq) }\end{array}$ & $\begin{array}{c}\text { Initial } \\
\text { Serum } \\
\text { Potassium } \\
(\mathrm{mEq} / \mathrm{l} .)\end{array}$ & $\begin{array}{c}\text { Lowest } \\
\text { Serum } \\
\text { Potassium } \\
\text { (mEq/1.) }\end{array}$ & $\underset{\text { Capillary }}{\text { Initial }}$ & $\begin{array}{c}\text { Highest } \\
\text { Recorded } \\
\text { Capillary } \\
\text { pH }\end{array}$ \\
\hline $\begin{array}{l}1 \\
2 \\
3 \\
4 \\
5 \\
6 \\
7 \\
8\end{array}$ & $\begin{array}{l}6 \cdot 25 \\
6 \cdot 5 \\
7 \\
5 \cdot 25 \\
6 \\
6 \\
6 \cdot 25 \\
6 \cdot 25 \\
\end{array}$ & $\begin{array}{l}4 \\
4 \\
5 \\
3 \cdot 5 \\
4 \\
4 \\
4 \\
4\end{array}$ & $\begin{array}{l}+1.31 \\
+2.93 \\
+3.89 \\
+2.17 \\
+2.46 \\
+1.32 \\
+1.09 \\
+2.12\end{array}$ & $\begin{array}{l}+151 \\
+429 \\
+629 \\
+415 \\
+446 \\
+269 \\
+267 \\
+395\end{array}$ & $\begin{array}{r}-49 \\
-104 \\
-45 \\
-43 \\
-113 \\
-18 \\
-57 \\
-77\end{array}$ & $\begin{array}{l}3 \cdot 7 \\
4 \cdot 0 \\
4 \cdot 2 \\
4 \cdot 1 \\
5 \cdot 0 \\
4 \cdot 2 \\
5 \cdot 2 \\
4 \cdot 6\end{array}$ & $\begin{array}{l}2 \cdot 7 \\
3 \cdot 0 \\
2 \cdot 9 \\
2 \cdot 8 \\
2 \cdot 9 \\
3 \cdot 1 \\
3 \cdot 6 \\
3 \cdot 0\end{array}$ & $\begin{array}{r}7 \cdot 22 \\
7.45 \\
7.45 \\
7 \cdot 27 \\
7.45 \\
7.44 \\
7.45\end{array}$ & $\begin{array}{l}7 \cdot 45 \\
7.54 \\
7.45 \\
7 \cdot 45 \\
7.44 \\
7.55 \\
7.54 \\
7.50\end{array}$ \\
\hline Av. & $6 \cdot 2$ & $4 \cdot 1$ & $+2 \cdot 15$ & +374 & -63 & $4 \cdot 4$ & 3.0 & $7 \cdot 39$ & $7 \cdot 49$ \\
\hline $\begin{array}{l}\mathbf{A} \\
\mathbf{B}\end{array}$ & $\begin{array}{c}10 \cdot 5 \\
8\end{array}$ & $\begin{array}{l}7 \\
4.9\end{array}$ & $\begin{array}{l}+2.75 \\
+1.53\end{array}$ & $\begin{array}{l}+593 \\
+376\end{array}$ & $\begin{array}{r}-96 \\
-8\end{array}$ & $\begin{array}{l}5 \cdot 9 \\
4 \cdot 7\end{array}$ & $\begin{array}{l}2 \cdot 7 \\
3 \cdot 5\end{array}$ & $\begin{array}{l}7 \cdot 54 \\
7 \cdot 40\end{array}$ & $\begin{array}{l}7.61 \\
7.59\end{array}$ \\
\hline
\end{tabular}
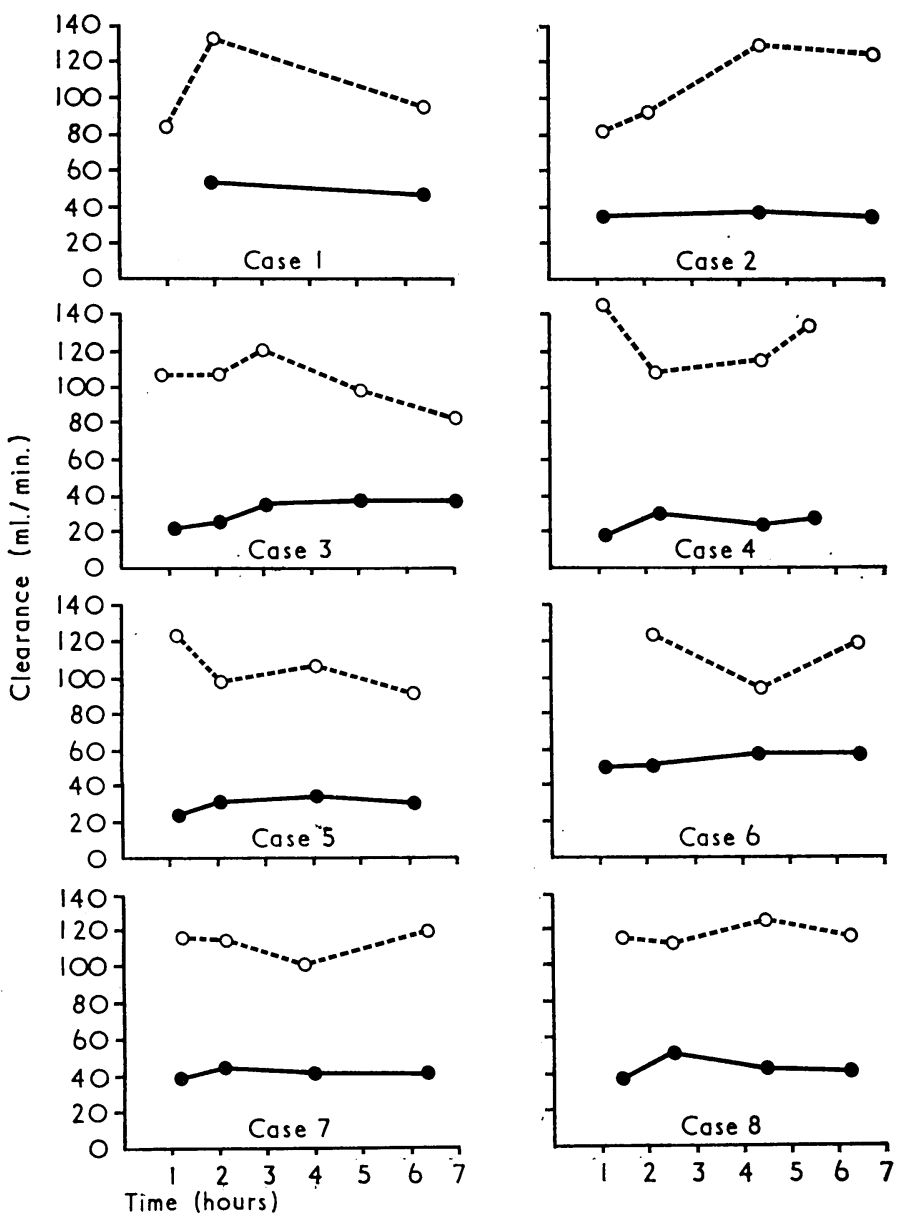

FIG. 2.-Salicylate clearance and creatinine clearance during treatment. Salicylate clearance (see Discussion) is shown by solid lines, and creatinine clearance by dotted lines. Acetazolamide was given at time zero.

\section{Discussion}

It is difficult to compare the effectiveness of the above treatment with that of other methods employed in adult cases of salicylate poisoning. Every report uses different criteria for salicylate removal, and clearances are not given in any, no doubt because of the difficulty of estimating free salicylate in the urine. The "half-life" has the important drawback that it is prolonged by continuous absorption of salicylate, but Cumming et al. (1964) and Ghose and Joekes (1964) quote a value of 7.5 hours and 12 hours respectively. By this criterion the present method, with a half-life of 6.3 hours, is satisfactory. An advantage, however, is the small volume of urine, and therefore of infused fluid, which was needed to reach this short

${ }^{1}$ The volumes quoted are those which had been given when the logarithm of the plasma salicylate level had been halved. half-life: the average input ${ }^{1}$ of 4.4 litres, compared with 6.25 litres (Ghose and Joekes, 1964) and approximately 8 litres (Cumming et al., 1964), reduces the likelihood of producing fluid and electrolyte imbalance in patients whose balance is of ten precarious at the start, and who often have to be treated in busy understaffed units. Table IV summarizes the differences in half-life, urine flow, and $p \mathrm{H}$ in our own cases treated by the present method and by a conventional alkaline diuresis regimen (Morgan et al., 1968). It emphasizes the favourable influence of a very high urine $p H$.

In a small series which included no old patients and none with an initial serum salicylate level above $90 \mathrm{mg} . / 100 \mathrm{ml}$., the fact that all the patients recovered without clinical complications is not remarkable, but the freedom from neurological complications is reassuring in view of the occurrence of convulsions in children (Schwartz et al., 1959). This difference is the more striking since three of our patients had had convulsions before treatment. It may be due to the dose of acetazolamide per kg., which was approximately half that used in children by Schwartz et al. and by Feuerstein et al. (1960).

TABLE IV.-Data to Show the Influence of Urine $p H$ on Salicylate

\begin{tabular}{|c|c|c|c|c|c|}
\hline & $\begin{array}{l}\text { No. of } \\
\text { Cases } \\
\text { Treated }\end{array}$ & $\begin{array}{c}\text { Mean } \\
\text { Salicylate } \\
\text { Half-life }\end{array}$ & $\begin{array}{c}\text { Mean } \\
\text { Urine } \\
p \mathbf{H}\end{array}$ & $\begin{array}{c}\text { Range } \\
\text { for Urine } \\
p \mathrm{H}\end{array}$ & $\begin{array}{c}\text { Average } \\
\text { Urine Flow } \\
\text { (ml./min.) }\end{array}$ \\
\hline \multirow{2}{*}{$\begin{array}{l}\text { Mannitol and } \\
\text { alkalitreatment* } \\
\text { Acetazolamide and } \\
\text { alkali treatment }\end{array}$} & $\begin{array}{l}5 \\
4\end{array}$ & $\begin{array}{l}17 \cdot 8 \\
11 \cdot 2\end{array}$ & $\begin{array}{l}6 \cdot 6 \\
7 \cdot 4\end{array}$ & $\begin{array}{l}6 \cdot 0-7 \cdot 05 \\
7 \cdot 2-7 \cdot 5\end{array}$ & $\begin{array}{l}7 \cdot 3 \\
7 \cdot 8\end{array}$ \\
\hline & 8 & $6 \cdot 3$ & $7 \cdot 88$ & $7 \cdot 6-8 \cdot 0$ & $5 \cdot 2$ \\
\hline
\end{tabular}

* Treatment as described by Morgan et al. (1968). The nine patients recciving this treatment are divided into two groups according to the urine $p \mathrm{H}$ achieved.

The absence of significant alkalosis in the present series is also reassuring. However, it has not been established that acetazolamide will always ensure that bicarbonate can be given without aggravating severe alkalosis, since only one of the patients (Case A) had an initial blood $p H$ as high as 7.54. It is encouraging that even this patient's $p H$ did not rise above 7.61 , though he was one of the two who received more bicarbonate than was laid down in the treatment regimen. Nevertheless it is premature to recommend this treatment without modification either for those few cases whose initial blood $\mathrm{pH}$ is above 7.6 or for those with severe metabolic acidosis. Where there is marked hyperventilation our present practice is to give only saline until the blood $\mathrm{pH}$ is known: if it is above 7.6 acetazolamide is given and bicarbonate omitted, while if it is below 7.25 the reverse applies.

Bicarbonate and acetazolamide may tend to aggravate the renal potassium wasting which is produced by salicylate (Robin et al., 1959). It was therefore anticipated that hypokalaemia might be more troublesome with this regimen than with previous methods of treatment, but it did not prove to be so. Nevertheless, it may be found that as soon as a diuresis occurs $(>2 \mathrm{ml} . / \mathrm{min}$.) a rate of potassium infusion of $30 \mathrm{mEq} /$ hour is preferable to that of $20 \mathrm{mEq} /$ hour employed here. In three cases in which this modification was adopted the serum potassium remained within normal limits. Another modification 
that might prove advantageous is the substitution of $5 \%$ dextrose for $0.9 \%$ saline in those patients who are initially hypernatraemic.

The values for salicylate clearance given in Table II and Fig. 2 cannot be compared with those of other authors as they are based on total serum salicylate concentrations-as measured by the method of Trinder (1954) - and not on the unbound fraction only. They are presented, nevertheless, because they provide the clinician with a rough estimate of the rate of salicylate excretion that he may obtain with acetazolamide and sodium bicarbonate infusion at any given serum salicylate level. In Fig. 2 creatinine clearance values are also shown, since the glomerular filtration rate is sometimes low in salicylate overdosage and may be further depressed by acetazolamide (Milne, 1963). The effectiveness of the treatment regimen might be limited by this, and also by competition for tubular secretion between acetazolamide and salicylate (Weiner et al., 1959).

Although this paper lays greater emphasis on a very high urine $p \mathrm{H}$ than a very high urine flow, it is clear that the rate of flow must still be a factor limiting salicylate clearance. When rehydration is not promptly followed by a brisk diuresis the use of an osmotic diuretic may therefore still be of value. We have unpublished data to show that the addition of mannitol to the present treatment regimen can further increase salicylate clearance. It should, however, be borne in mind that mannitol may cause complications of its own (Morgan et al., 1968).

It is not suggested that acetazolamide and sodium bicarbonate treatment will replace haemodialysis in the severest cases of salicylate intoxication, for in these there may be other indications for dialysis than the serum salicylate concentration. However, the concentration itself may of ten be brought down to a safer level during the time required to transfer a patient to a dialysis unit. We have recently treated two such patients prior to dialysis, reducing the serum salicylate in one from 136 to $107 \mathrm{mg} . / 100 \mathrm{ml}$. in two hours, and in the other from 104 to $69 \mathrm{mg}$. $/ 100 \mathrm{ml}$. in three hours.
We wish to thank Professor M. J. H. Smith, Dr. H. A. Lee, and Dr. H. Miller for their helpful comments ; Dr. J. M, S. Knott for allowing us to study patients under his care; and Sister Johnson and the nursing staff of the intensive care unit, Royal Portsmouth Hospital, for their skilled assistance.

The modification of Brodie's method for urinary salicylic acid estimation was suggested by Dr. A. J. Cummings, of the Nicholas Research Institute.

A. G. M. was in receipt of a research grant from the Wessex Regional Hospital Board.

\section{REFERENCES}

Beveridge, G. W., Forshall, W., Munro, J. F., Owen, J. A., and Weston, I. A. G. (1964). Lancet, 1, 1406.

Brodie, B. B., Undenfriend, S., and Coburn, A. F. (1944). F. Pharmacol. exp. Ther., 80, 114

Counihan, T. B., Evans, B. M., and Milne, M. D. (1954). Clin. Sci.

13, 583.
Cumming, G., Dukes, D. C., and Widdowson, G. (1964). Brit. med. F.,

2, 1033.

Done, A. K. (1960). Pediatrics, 26, 800.

Dukes, D. C., Blainey, J. D., Cumming, G., and Widdowson, G. (1963). Lancet, $2,329$.

Feuerstein, R. C., Finberg, L., and Fleishman, E. (1960). Pediatrics,

25, 215 .
Ghose, R. R., and Joekes, A. M. (1964). Lancet, 1, 1409.

MacPherson, C. R., Milne, M. D., and Evans, B. M. (1955). Brit. F. Pharmacol., 10, 484.

Matthew, H., and Lawson, A. A. H. (1967). Treatment of Common Acute Poisonings, p. 33. Edinburgh.

Milne, M. D. (1963). In Salicylates, edited by A. St. J. Dixon, B. K. Martin, M. J. H. Smith, and P. H. N. Wood, p. 19. London.

Morgan, A. G., Bennett, J., and Polak, A. (1968). Quart. F. Med., 37, 589.

Pitts, R. F., Ayer, J. L., and Schiess, W. A. (1949). F. clin. Invest.,

Robin, E. D., Davis, R. P., and Rees, S. B. (1959). Amer. F. Med., 26, 869 .

Schwartz, R., Fellers, F. X., Knapp, J., and Yaffe, S. (1959). Pediatrics, 23, 1103.

Smith, P. K.. Gleason, H. L., Stoll, C. G., and Ogorzalek, S. (1946). 7. Pharmacol. exp. Ther., 87, 237.

Trinder, P. (1954). Biochem. f., 57, 301.

Weiner, I. M., Washington, J. A., and Mudge, G. H. (1959). Bull. fohns Hopk. Hosp., 105, 284.
* Senior Lecturer in Medicine, King's College Hospital, London S.E.5. Assistant, Department of Radiotherapy, Royal Sussex County Hospital, Brighton.

‡ Senior Registrar, Department of Medicine, King's College Hospital, London S.E.5; formerly Senior Medical Registrar, Royal Sussex County Hospital, Brighton.

Shysicist, Physics Department, King's College Hospital, London S.E.5. if Scanning Room Technician, Physics Department, King's College Hospital, London S.E.5.

\section{Introduction}

Patients with back pain present difficulties in diagnosis when the radiological features are normal or show changes which can be interpreted in more than one way. It has been estimated that at least a $30 \%$ alteration in bone density must take place before changes can be detected by conventional radiological techniques (Lachman, 1955). Tomography may improve the delineation of the lesion, but some idea of the area involved must be given first.

Normal bones accumulate radioisotopes by a variety of processes which involve simple exchange diffusion, active transport, and incorporation into bone mineral (Bauer, Carlsson, and Lindquist, 1958). Increased uptake in a particular area of bone may be due to increased blood flow, altered exchange processes, or new bone formation. These changes arise in the repair processes involved in traumatic, inflammatory, and neoplastic lesions, micro-fractures probably occurring in most of the vertebral diseases of this nature. In neoplastic lesions a variety of causes may lead to an increased uptake, including osteolysis opening up a large area for exchange, new bone formation in sclerotic deposits, and, on occasion, osteomalacia (Follis, 1950). Bone biopsy of areas which had shown increased ${ }^{85} \mathrm{Sr}$ uptake 